\title{
Chemical and Hot Water Treatments to Control Rhizoctonia AG P Infesting Stem Cuttings of Azalea
}

\author{
Warren E. Copes ${ }^{1,3}$ \\ USDA-ARS, Thad Cochran Southern Horticultural Laboratory, 810 Highway \\ 26 West, P.O. Box 287, Poplarville, MS 39470
}

\author{
Eugene K. Blythe ${ }^{2}$ \\ Coastal Research and Extension Center, Mississippi State University, South \\ Mississippi Branch Experiment Station, Poplarville, MS 39470
}

Additional index words. azalea web blight, Rhododendron 'Gumpo White', vegetative propagation, disinfestants, disinfectants, fungicides, thermotherapy

\begin{abstract}
In the southern and eastern United States, azalea stems cut during the spring for propagation may be infested with Rhizoctonia spp. Multiple methods were evaluated in a series of laboratory experiments for the purpose of eliminating Rhizoctonia from stem cuttings of Rhododendron L. 'Gumpo White' ['Gumpo White' (Satsuki) azalea] to prevent spread of azalea web blight during the propagation phase of nursery production. Leafless stem sections were inoculated with an isolate of binucleate Rhizoctonia anastomosis group P (AG P). Disinfestants (sodium hypochlorite, hydrogen dioxide, and quaternary ammonium chloride) or fungicides (chlorothalonil + thiophanate-methyl and flutolanil) applied at several rates (below, at, and above label rates) did not eliminate Rhizoctonia AG P from stem sections. Recovery of Rhizoctonia AG P was not reduced by submersing stem pieces in $45^{\circ} \mathrm{C}$ water, but was eliminated at water temperatures of $50^{\circ} \mathrm{C}$ or greater. Mortality of Rhizoctonia infesting azalea stem pieces was best explained by a cubic regression model. Mortality increased with increasing time $(0,1.5,3,4.5,6,7.5,9$, $10.5,12,15,18$, and $21 \mathrm{~min})$ in water at 50 and $55^{\circ} \mathrm{C}$ and with increasing temperatures $\left(52,55,58,61,64,67\right.$, and $\left.70^{\circ} \mathrm{C}\right)$ when stem pieces were submerged for 30 and $60 \mathrm{~s}$. The duration of hot water treatment at which $99 \%$ of stem pieces were predicted to be free of Rhizoctonia was $20 \mathrm{~min} 16 \mathrm{~s}$ at $50{ }^{\circ} \mathrm{C}$ and $5 \mathrm{~min} 19 \mathrm{~s}$ at $55^{\circ} \mathrm{C}$. The average water temperature at which $99 \%$ of the stem pieces were predicted to be free of Rhizoctonia was 60.2 and $56.9^{\circ} \mathrm{C}$ when stem pieces were submerged for 30 and $60 \mathrm{~s}$, respectively. Only minor leaf damage occurred on terminal, leafy stem cuttings when submerged in $50{ }^{\circ} \mathrm{C}$ water after $\mathbf{4 0} \mathrm{min}$. Severe leaf damage did occur if cuttings were submerged long enough in water of $55{ }^{\circ} \mathrm{C}$ or greater. Leaf damage was predicted to exceed a proportional leaf damage value of 0.25 (indicating severe damage) when leafy stem cuttings were submerged in $55{ }^{\circ} \mathrm{C}$ water for longer than $13 \mathrm{~min} 54 \mathrm{~s}$ or for 30 and $60 \mathrm{~s}$ with water temperature greater than 57.4 and greater than $56.8^{\circ} \mathrm{C}$, respectively. Of the methods tested, submersion in hot water has the greatest potential for eliminating Rhizoctonia AG $P$ from azalea stem cuttings. Submerging stem pieces in $50^{\circ} \mathrm{C}$ water for 21 min eliminated Rhizoctonia and provided the least risk for development of severe leaf damage.
\end{abstract}

Azalea web blight is an annual problem on some evergreen azalea cultivars grown in containerized nursery production in the

\footnotetext{
Received for publication 2 Apr. 2009. Accepted for publication 4 June 2009.

We acknowledge Lavonne Stringer who maintained the isolate, generated inoculum, and assisted with experiments and Whitney Sumpter who collected and inoculated azalea stem pieces and assisted with experiments.

Mention of a trademark, proprietary product, or vendor does not constitute a guarantee or warranty of the product by the Department of Agriculture or Mississippi State University and does not imply its approval to the exclusion of other products or vendors that may also be suitable.

${ }^{1}$ Research Plant Pathologist.

${ }^{2}$ Assistant Research Professor.

${ }^{3}$ To whom reprint requests should be addressed; e-mailwarren.copes@ars.usda.gov.
}

southern and eastern United States. Rhizoctonia AG P (equivalent to Rhizoctonia AG U) is the primary anastomosis group (AG) of the binucleate Rhizoctonia species that causes web blight on azalea (Rinehart et al., 2007). From field observations made during a study by Rinehart et al. (2007), it was noticed that azalea plants symptomatic of web blight were randomly distributed within blocks of the same cultivar yet regularly distributed across most azalea cultivars of differing susceptibility, plants of differing age (from newly potted cuttings to 4-year-old plants), and blocks arbitrarily located across nurseries that may be greater than 100 acres at a single site (Frisina and Benson, 1989; Rinehart et al., 2007). The mechanisms by which Rhizoctonia spp. are spread in agricultural field and row crops are generally known (Tsror and Peretz-Alon, 2005; Yuan et al., 2006). In field and row crops, soil character- istics and ecology affect conduciveness and pathogen distribution within a field, factors that have been used to develop recommendations such as deep plowing of crop residues (Lewis et al., 1983). Part of the disparity in pathogen dispersion concepts between fieldand nursery-grown crops occurs because Rhizoctonia spp. are soilborne organisms. In nursery crops in the southern and eastern regions of the United States, pine bark is the most common growing substrate component and new bark-based substrate is used for each year's crop. Container-grown, woody ornamental crops also differ from field crops in that their production time extends over more than a single year, plants are physically handled multiple times during production, and plants are freely relocated to accommodate changing space and plant inventory needs at a nursery. Part of the distribution pattern of Rhizoctonia AG P may be explained by the discovery that as many as $20 \%$ of stems with new stem growth can be colonized by Rhizoctonia AG P during the spring when those stems are harvested for vegetative propagation (W.E. Copes, unpublished data). Rhizoctonia spp. are spread on cuttings of a variety of ornamental plants (Benson, 1992; Chase, 1991; Smith and Neely, 1981).

Best management practices for propagation of pathogen-free plants include the use of clean rooting substrate, the collection of cuttings from disease-free plants, and the use of sanitary propagation facilities. If the first two conditions cannot be guaranteed, generally accepted practices are to pasteurize substrate, treat stock plants with fungicides, and/ or dip cuttings in a disinfestant or fungicide solution (Daughtrey and Benson, 2005; Williams-Woodward and Jones, 2001). A number of methods, including treatment with disinfestants or fungicides, submersion in hot water, and exposure to ultraviolet radiation, have been used for disinfesting a variety of plant material such as fruits, ornamental plants (bulbs, corms, stem cuttings), seeds, and vegetables (du Toit and Hernandez-Perez, 2005; Johnson et al., 2006; Keck et al., 1995; Lurie, 2006; Mannini, 2007; Mari et al., 2007; Porat et al., 2002; Sharma and Tripathi, 2008; Tsang et al., 2003; Ukuku, 2006). Various disinfestants and fungicides have been used to sanitize carrots, poinsettia cuttings, seed potatoes, and sugar beets of Rhizoctonia spp. (Amadioha, 1998; Benson, 1991; European and Mediterranean Plant Protection Organization, 1994; Fleury, 1992; Ricker and Punja, 1991; Weinhold et al., 1982). R. solani has been reported to be thermally killed in soils with sustained temperatures of $53{ }^{\circ} \mathrm{C}$ (Baker and Roistacher, 1972).

The objective of this work was to evaluate the efficacy of disinfesting methods to eliminate Rhizoctonia from azalea stems without damaging leaf tissue of azalea stem cuttings. An initial series of experiments was performed to evaluate efficacy with a small number of levels (rates, temperatures, submersion times) of different types of disinfesting methods. When certain methods were shown 
to cause significant reduction in the recovery of Rhizoctonia AG P from azalea stem pieces, further experiments were constructed with a broader range of factor levels. The results from this research will be tested in the field in subsequent studies.

\section{Materials and Methods}

Stem preparation and inoculation. In preparation for inoculation of stem pieces, pathogen-infested rice was prepared by placing $25 \mathrm{~g}$ dry white rice grains and $18 \mathrm{~mL}$ deionized water in a $250-\mathrm{mL}$ Erlenmeyer flask and closing the flask with a foam plug. The flask and contents were autoclaved at $125{ }^{\circ} \mathrm{C}$ for $60 \mathrm{~min}$. After cooling to room temperature, the rice was stirred using aseptic methods in a biohazard IIA hood. Three 0.49$\mathrm{cm}^{2}$ square blocks of potato dextrose agar (PDA) with the leading edge of mycelium of 3- to 5-d-old cultures of Rhizoctonia AG P (isolate RhFB076WAz4, collected from azalea) were aseptically dropped onto the moistened rice of a single flask. Cultures were grown for 7 to $10 \mathrm{~d}$ at $23{ }^{\circ} \mathrm{C}$ in the dark. One to two flasks of inoculum were started in advance of each experiment.

Stem cuttings for all experiments were collected from a single group of 'Gumpo White' azalea plants grown in 3.8-L containers and maintained outside from May to September and in a greenhouse from October to November at the USDA-ARS Thad Cochran Southern Horticultural Laboratory in Poplarville, MS. Stem sections of variable length and $3 \mathrm{~mm}$ or less diameter were obtained from plants on the same day of inoculation. Leaves were removed before stem pieces were inoculated with Rhizoctonia AG P. Studies were performed from May 2008 to Nov. 2008.

Two inoculation procedures were used: a buried stem inoculation (BSinoc) method and an upright stem inoculation (USinoc) method. The BSinoc method was used for most experiments, because it was easy to set up and maintain. For the BSinoc method, a 1.2-cm-deep layer of moistened peatbased substrate (Fafard 2B; Conrad Fafard, Agawam, MA) was placed in the bottom of a $25.4 \mathrm{~cm} \times 25.4-\mathrm{cm}$ plastic tray. Infested rice grains $(20 \mathrm{~g})$ were evenly distributed on the substrate layer and then covered with a $0.6-\mathrm{cm}$-deep layer of the peat-based substrate. Stem pieces were laid horizontally and evenly distributed on the second layer of substrate and then covered with a $1.2-\mathrm{cm}-$ deep top layer of the peat-based substrate. Deionized water was added as needed using a trigger spray bottle. The tray was covered with a clear plastic lid to reduce water loss from evaporation and maintained at $21{ }^{\circ} \mathrm{C}$ on a laboratory shelf. After stem pieces were exposed to colonization by Rhizoctonia AG P for 3 , 5, or $7 \mathrm{~d}$, stem pieces were removed with forceps and gently brushed to remove most of the substrate and cut to $3-\mathrm{cm}$ lengths.

The purpose of the USinoc method was an attempt to produce a mycelium growth habit similar to what would occur on stems in the canopy of an azalea plant. The USinoc method involved a bottom 1.2-cm-deep layer of peat-based substrate, a layer of infested rice $(20 \mathrm{~g})$, and a 1.2-cm-thick top layer of the peat-based substrate in a $25.4 \mathrm{~cm} \times 25.4-\mathrm{cm}$ plastic tray. Vertically orientated stem pieces were inserted into the peat until the cut ends butted against the bottom of the tray. Stem pieces were arranged in rows that alternated between strips of fiberglass air filter material (Ace 10004.011425 Furnace Filter, $35.6 \times$ $63.5 \times 2.5 \mathrm{~cm}$; Flanders-PrecisionAire, Inc., Washington, NC). A fiberglass filter strip $\approx 1.5 \mathrm{~cm}$ wide was set on the surface of the substrate against a side of the plastic tray. A straight row of 10 vertical stem pieces was inserted into the substrate so that they pressed against the fiberglass filter. Another fiberglass filter strip was set on the surface of the substrate and pressed against that row of stem pieces. The process was repeated until ending with a fiberglass filter strip at the opposite side of the tray. The tray was maintained on a greenhouse bench at $25^{\circ} \mathrm{C}$ and watered with an overhead, intermittent misting system. Irrigation mist was applied for 10-s durations at 30-min intervals from $700 \mathrm{HR}$ to $2100 \mathrm{HR}$. The purpose of the fiberglass filter was to provide large air spaces that restricted air flow around the stem pieces to create a higher relative humidity microenvironment than ambient air, similar to the environment found within the canopy of an azalea plant. After 5 to $9 \mathrm{~d}$, stem pieces were removed with forceps and the lower $2.5 \mathrm{~cm}$ that was buried in substrate and uppermost section that extended above the filter layer were cut off with pruning shears, resulting in $3-\mathrm{cm}$ stem pieces. After each inoculation procedure for both inoculation methods, three stem pieces were arbitrarily selected and microscopically examined. Stem pieces were used in studies when mycelium growth was regularly distributed around the entire circumference and length of the stem pieces. Mycelium distribution was similar for both inoculation methods.

Stem cutting preparation. Terminal stem cuttings, $3 \mathrm{~cm}$ in length, were used to evaluate leaf damage in response to hot water treatments. These cuttings were collected from the same 'Gumpo White' azalea plants from which stem pieces were obtained for inoculation as previously described. Cuttings were collected during the morning, placed in a plastic bucket, and kept covered with a moist paper towel. Leaves were removed from the basal $0.5-\mathrm{cm}$ portion of the stem in the laboratory. Cuttings with leaves were not inoculated with Rhizoctonia AG P or subjected to chemical treatments.

Chemical treatments. A series of experiments (Expts. 1 to 4 ) were conducted using selected chemicals (disinfestants and fungicides) and rates applied to stem pieces inoculated with Rhizoctonia AG P (Table 1). A total of $250 \mathrm{~mL}$ of each treatment solution was prepared and poured into a $600-\mathrm{mL}$ beaker. Six stem pieces were randomly selected for each treatment, placed in the solution, and swirled to provide thorough wetting. Stem pieces were submersed for selected durations (Table 1) by setting a second beaker into the solution, dispersing trapped air, and pushing downward until solution rose between the walls of the two beakers. Each experiment (except Expt. 2) was repeated with repetitions designated as Run 1 and Run 2.

Stem pieces treated with a disinfestant (sodium hypochlorite, hydrogen peroxide, or quaternary ammonium chloride) were set on water agar (WA) medium within minutes after treatment. Stem pieces treated with a fungicide (chlorothalonil + thiophanatemethyl or flutolanil) were allowed to dry for at least $2 \mathrm{~h}$ before setting on WA medium. Plates were examined daily for $7 \mathrm{~d}$ for the presence of Rhizoctonia. Rhizoctonia was verified based on observing macroscopic mycelium branching traits in WA by viewing the reverse side of plates held toward a fluorescent light and microscopic examination of mycelium. A small number of samples were additionally plated on half-strength PDA to verify identification.

Hot water treatments. For hot water treatments, 19-L and 15-L circulating water baths (Models 260 and 280, respectively; Precision-NAPCO, A Division of Joshua, Inc., Winchester, VA) were used to bring deionized water to the desired treatment temperature (Table 1). Approximately $800 \mathrm{~mL}$ of water was scooped from the hot water bath into each of two 1000-mL glass beakers and then the beakers were set down into the hot water bath. Leafless stem pieces inoculated by the BSinoc method were dropped into water in a separate beaker than noninoculated, terminal stem cuttings with leaves. Stem pieces and cuttings were stirred for 2 to $3 \mathrm{~s}$ until submerged. A metal lid was used to cover the opening of the hot water bath and lifted each time stem pieces were removed. Water temperature was recorded using a partial immersion thermometer in the hot water bath and in the beakers at the start and finish of a replication. Before the next replication, water within the beakers was discarded, deionized water was added back to the hot water bath and allowed to reach the required temperature, and then the process was repeated.

Stem pieces and cuttings were removed from the water with forceps. Leafless stem pieces were immediately set on WA medium, whereas cuttings with leaves were placed in humid chambers (31-L and 16-L plastic boxes with snap-closure lids and with wet paper towels lining the bottom on the inside of the box). WA plates were checked daily for $7 \mathrm{~d}$ for the presence of Rhizoctonia as previously described. Leaf damage on the cuttings was rated after $24 \mathrm{~h}$ by counting the number of leaves per cutting that appeared healthy $(\mathrm{H})$, that exhibited damage (leaf discoloration) on less than $50 \%$ leaf area (LDlt50), and that exhibited damage on greater than $50 \%$ leaf area (LDgt50). A proportional leaf damage (LfD) value was calculated per cutting using the following 
Table 1. Experiment number, treatment description, and type of tissue treated in a series of experiments examining efficacy of chemicals (disinfestants and fungicides) and hot water exposures (temperature and duration) for eliminating Rhizoctonia AG P from stem cuttings of 'Gumpo White' azalea.

\begin{tabular}{|c|c|c|}
\hline Expt. $^{z}$ & Chemical and hot water treatments & Tissue \\
\hline 2 & $\begin{array}{l}\text { Chlorothalonil + thiophanate-methyl } \mathrm{r}^{\mathrm{r}} \text { at } 0,0.431,0.863^{\mathrm{t}} \text {, or } 1.726^{\mathrm{t}} \mathrm{g} \cdot \mathrm{L}^{-1} \text { a.i. }+0.108,0.216 \text {, or } \\
0.431 \mathrm{~g} \cdot \mathrm{L}^{-1} \text { a.i., respectively, for } 3 \text { to } 4 \mathrm{~s} \text {; flutolanil }{ }^{\mathrm{q}} \text { at } 0,157.5^{\mathrm{t}}, 315 \text {, or } 630^{\mathrm{t}} \mathrm{mg} \cdot \mathrm{L}^{-1} \text { a.i. } \\
\text { for } 3 \text { to } 4 \mathrm{~s}\end{array}$ & Stem pieces inoculated ${ }^{v}$ for $7 \mathrm{~d}$ \\
\hline 3 & $\begin{array}{l}\text { Deionized water for } 10 \mathrm{~min} \text {; sodium hypochlorite at } 12.20 \mathrm{~mL} \cdot \mathrm{L}^{-1} \text { a.i. for } 10 \mathrm{~min} \text {; flutolanil } \\
\text { at } 0.315 \mathrm{~g} \cdot \mathrm{L}^{-1} \text { a.i. for } 3 \text { to } 4 \mathrm{~s}\end{array}$ & $\begin{array}{l}\text { Stem pieces inoculated } \mathrm{d}^{\mathrm{p}} \text { for } 3 \text {, } \\
5 \text {, and } 7 \mathrm{~d}\end{array}$ \\
\hline 6 & Hot water at $52,55,58,61,64,67$, or $70^{\circ} \mathrm{C}$ for 0,30 , and $60 \mathrm{~s}$ & $\begin{array}{l}\text { Stem pieces inoculated }{ }^{v} \text { for } 7 \mathrm{~d} \text {, } \\
\text { terminal stem cuttings }\end{array}$ \\
\hline
\end{tabular}

${ }^{\mathrm{z}}$ All experiments, except Expt. 2, were repeated in two runs.

${ }^{\mathrm{y}}$ Clorox bleach.

“" 0 " value is deionized water only.

${ }^{\mathrm{w}}$ Common rate used by the industry, 9:1 (v:v) water:product.

${ }^{v}$ Stem pieces were infested with Rhizoctonia AG P by covering with moist peat-based substrate containing colonized rice grains as inoculum. Substrate containing the stem pieces was hand-misted periodically, enclosed in a covered plastic container, and maintained at $21{ }^{\circ} \mathrm{C}$ on a laboratory shelf.

"Zerotol (Biosafe Systems, GlastonBury, CT).

tRegistered rate listed on Environmental Protection Agency-approved label. Consult labels for specific use recommendations.

${ }^{\mathrm{s}}$ Green Shield (Whitmire Micro-Gen Research Laboratories, Inc., St. Louis, MO).

${ }^{r}$ Spectro 90 (Cleary Chemical, Dayton, NJ).

${ }^{\mathrm{q}}$ Contrast (Scotts-Sierra Crop Protection Co., Marysville, $\left.\mathrm{OH}\right)$.

${ }^{\mathrm{p}}$ Leafless stem pieces were infested with Rhizoctonia AG P by vertical insertion in moist peat-based substrate containing colonized rice grains as inoculum. A higher-than-ambient relative humidity around the aerial portion of the stem was favored by contiguous covering of the peat surface with a $2.54-\mathrm{cm}$-thick strip of fiberglass furnace filter. Stem pieces were incubated in a greenhouse under an intermittent mist system.

${ }^{\circ}$ Surf-Ac 820 (Drexel Chemical Co., Memphis, TN).

${ }^{\mathrm{n}}$ Terminal stem cuttings were used to assess leaf damage in response to hot water treatment and not used with solutions containing sodium hypochlorite.

formula (where TLN is the total leaf number per cutting $): \mathrm{LfD}=[(\mathrm{LD} l \mathrm{t} 50 / \mathrm{TLN}) \times 0.25]+$ $[(\operatorname{LDgt} 50 / \mathrm{TLN}) \times 0.75]$. The midpoint value of each category was selected as multipliers to assess leaf damage. LfD is a "leaf damage" value, whereby the likelihood of a stem cutting to not successfully develop roots would be correlated to the proportional number of leaves per stem that were healthy, had less than $50 \%$ necrotic area, and had greater than $50 \%$ necrotic area. Damage to stem cuttings was categorized as none (all leaves green and healthy in appearance), moderate (LfD 0.25 or less; should not affect success of rooting), and severe (LfD greater than 0.25; likely to affect rooting success).

Statistical analysis. In all six experiments, treatment efficacy was measured as a binary response of recovery or no recovery of Rhizoctonia (with no recovery also referred to as elimination of Rhizoctonia). In Expts. 4 to 6 , leaf damage data were collected as a continuous response variable, the calculation of which was described in the previous section.

A completely randomized design was used in Expts. 1 to 3 with random assignment of stem pieces or stem cuttings to experimental treatments. No statistical analysis was conducted in Expts. 1 to 3 because there was no elimination of Rhizoctonia from stem pieces with any treatment.

A completely randomized design was used in Expt. 4. Associations were analyzed with Mantel-Haenszel $\chi^{2}$ tests using the FREQ procedure of SAS (Version 9.1.3; SAS Institute, Inc., Cary, NC), because stratified variables were ordinally scaled and the response was dichotomous. Data were treated as nonparametric standardized midrank scores, using modified Ridit scores, to avoid potential distribution problems. For the binary response of recovery of Rhizoctonia, the null hypothesis was one of general association. For the ordinal leaf damage response, the null hypothesis was one of shifts in row mean scores. When more than one-third of the treatment responses had a frequency of five or less, exact $P$ values were calculated using Fisher's exact test.

A split plot design was used in Expts. 5 and 6 with a main plot factor, subplot factor, and replication as a block effect by time. In Expt. 5, the main plots (two temperatures) were replicated four times, and the subplots (12 durations of exposure) were replicated three times within each main plot. In Expt. 6, the main plots (two durations of exposure) and subplots (seven temperatures) were replicated 12 times in Run 1 and seven times in Run 2.

For Expt. 5, the binary response of elimination of Rhizoctonia was analyzed using probit regression with the PROBIT procedure of SAS to calculate lethal dose curves and to compare intercept and slope parameters between factors and runs. In Expt. 6, the binary response of elimination of Rhizoctonia was analyzed with generalized linear mixed models (with a binomial distribution and probit link) with the GLIMMIX procedure of SAS.

In Expt. 5, leaf damage data were analyzed using the MIXED procedure of SAS with independent variables being temperature and linear, quadratic, and cubic effects of duration of exposure. Duration of exposure was treated as a continuous variable in the model statement. Random effects were experiment, experiment with replication and subplot replication, and the previous effects with temperature and duration of exposure. In Expt. 6, leaf damage data were analyzed using the MIXED procedure of SAS with independent variables being duration of exposure and linear, quadratic, and cubic effects of temperature. Temperature was treated as a continuous variable in the model statement. Heterogeneous variances were fit using the Toeplitz covariance structure. Replication was defined as an independent random effect using the SUBJECT option in a REPEATED statement.

\section{Results}

In Expts. 1 and 2, none of the disinfestant or fungicide treatments (Table 1) resulted in elimination of Rhizoctonia AG P; rather, Rhizoctonia was recovered from all stem pieces (data not shown). These results were unexpected, because it might be assumed that one or more of these treatments would have reduced recovery of the pathogen.

In Expt. 3, the duration of stem exposure to colonization by Rhizoctonia AG P $(3,5$, and $7 \mathrm{~d}$ ) resulted mostly in no differences among treatments (deionized water, sodium hypochlorite, and flutolanil) (data not shown). Rhizoctonia AG P was recovered from $100 \%$ of the leafless stem pieces in Run 1 and from $100 \%$ of the leafless stem pieces treated with deionized water and sodium hypochlorite in Run 2. A reduction in the recovery of Rhizoctonia from leafless stem cuttings 
treated with flutolanil was negatively correlated $(P<0.0001)$ with increasing number of days that stem pieces were colonized by the fungus.

In Expt. 4, response frequencies were nearly identical between the two runs for each treatment; therefore, data were combined across levels. Treatments (deionized water, sodium hypochlorite, $45^{\circ} \mathrm{C}$ water, and $55{ }^{\circ} \mathrm{C}$ water $)$ were different $(P<0.0001)$ (Table 2). Rhizoctonia was not recovered from stem pieces submersed in $55^{\circ} \mathrm{C}$ water whether for 5,25 , or $45 \mathrm{~min}$, but was recovered at a high frequency from all other treatments.

In Expt. 4, the leaf damage responses to hot water treatments were similar between runs; therefore, data were combined across runs for analysis. LfD values tended to remain below the 0.25 level, then increase to above the 0.25 level, and then increase readily to the 0.75 level; therefore, the 0.25 value was selected as the demarcation between moderate and severe leaf damage (Figs. 1 and 2). Treatments [deionized water $\left(21^{\circ} \mathrm{C}\right), 45^{\circ} \mathrm{C}$ water, and $55^{\circ} \mathrm{C}$ water $]$ across ranked $\mathrm{LfD}$ values were different $(P<$ 0.0001 ) (Table 2). No leaf damage resulted from submersion in $21{ }^{\circ} \mathrm{C}$ water, very minor damage occurred from submersion in $45^{\circ} \mathrm{C}$ water, and pronounced leaf damage resulted from submersion in $55{ }^{\circ} \mathrm{C}$ water. An additional analysis was done for leaf damage in association with the duration of submersion at $55^{\circ} \mathrm{C}$. Treatments (submersion for $0,5,25$, and $45 \mathrm{~min})$ were different $(P<0.0001)$ (Table 3). The frequency of severe leaf damage per stem increased with increasing duration of submersion in $55^{\circ} \mathrm{C}$ water.

In Expt. 5, Rhizoctonia was eliminated from azalea stem pieces with increasing duration of exposure to hot water at 50 and $55{ }^{\circ} \mathrm{C}$ (Fig. 1). The response was different between temperatures within Runs 1 and 2 as a result of differences in slopes $(P<0.0001$ and $P=0.0002$, respectively). The response was different between runs at each temperature but varied as to whether they differed as a result of the intercept or slope. At $50{ }^{\circ} \mathrm{C}$, runs were different as a result of the intercept $(P=0.0377)$ but not the slope $(P=0.8601)$; the intercept (SE) and slope (SE) were -2.130 $(0.329)$ and $0.286(0.042)$ for Run 1 and

Table 2. Percent recovery of Rhizoctonia AG P from inoculated, leafless stem pieces of 'Gumpo White' azalea treated with sodium hypochlorite or submerged in hot water for a duration of time, and frequency of damage to terminal stem cuttings resulting from submersion in hot water.

\begin{tabular}{lccccc}
\hline & & & \multicolumn{3}{c}{ Frequency of cuttings with leaf damage ${ }^{\mathrm{y}}$} \\
\cline { 3 - 6 } Treatment & $\mathrm{n}^{\mathrm{z}}$ & Recovery $(\%)$ & None & Moderate & Severe \\
\hline Deionized water & 12 & 83 & 12 & 0 & 0 \\
Sodium hypochlorite & 24 & 75 & Not tested & Not tested & Not tested \\
$45^{\circ} \mathrm{C}$ water & 36 & 72 & 35 & 1 & 0 \\
$55^{\circ} \mathrm{C}$ water $^{\mathrm{x}}$ & 36 & 0 & 7 & 9 & 20 \\
\hline
\end{tabular}

${ }^{\mathrm{z}}$ Includes combined data from two runs (repeated experiment).

y Damage to stem cuttings was categorized as none (all leaves green and healthy in appearance), moderate (LfD 0.25 or less; should not affect success of rooting), and severe (LfD greater than 0.25 ; likely to affect rooting success). LfD is a "leaf damage" value whereby the likelihood of a stem cutting to not successfully develop roots would be correlated to the proportional number of leaves per stem cutting that were healthy, had less than $50 \%$ necrotic area, and had greater than $50 \%$ necrotic area.

${ }^{\mathrm{x}}$ Frequencies include combined data for 5-, 25-, and 45-min durations. cubic response in both experiments). Based on cubic regression equations, plant damage exceeded the 0.25 severity rating with submersion in 60.9 and $57.4{ }^{\circ} \mathrm{C}$ water for $30 \mathrm{~s}$ in Runs 1 and 2, respectively, and in 60.6 and $56.8{ }^{\circ} \mathrm{C}$ water for $60 \mathrm{~s}$ in Runs 1 and 2 , respectively (Fig. 2).

\section{Discussion}

Based on results from these laboratory experiments, submersion in hot water was the only effective treatment for eliminating binucleate Rhizoctonia AG P, the cause of azalea web blight, from azalea stem cuttings used for propagation. However, hot water treatment carries the risk of damaging plant tissue. Based on these experiments, the safety margin in time between the point when Rhizoctonia is eliminated and the point when severe plant damage develops is greater at $50{ }^{\circ} \mathrm{C}$ than at $55^{\circ} \mathrm{C}$. At $50{ }^{\circ} \mathrm{C}$, Rhizoctonia was eliminated after $20 \mathrm{~min}$, whereas severe plant damage did not occur even at the maximum submersion time of $40 \mathrm{~min}$. At $55{ }^{\circ} \mathrm{C}$, Rhizoctonia was eliminated after only 5 min, but severe plant damage occurred after $13 \mathrm{~min}$. With only a slight increase in water temperature to 58 and $60^{\circ} \mathrm{C}$, Rhizoctonia was eliminated in $60 \mathrm{~s}$ and $30 \mathrm{~s}$, respectively. However, stem submersions for $60 \mathrm{~s}$ and $30 \mathrm{~s}$ are predicted to cause severe plant damage at 57 and $58{ }^{\circ} \mathrm{C}$, respectively, which is slightly below the temperature predicted to eliminate Rhizoctonia. Obviously, greater safety margins are achieved with the cooler water temperatures. Rhizoctonia was not eliminated by submerging inoculated azalea stem pieces in $45{ }^{\circ} \mathrm{C}$ water for a maximum of $45 \mathrm{~min}$. It is not known whether longer durations could have been lethal to the pathogen. Botrytis allii infections were reduced by submerging onions in $45{ }^{\circ} \mathrm{C}$ water for 8 to $12 \mathrm{~h}$ (Grondeau and Samson, 1994). Our estimation of how long to submerse stems to eliminate Rhizoctonia is likely conservative, because stem pieces were artificially inoculated. It is likely that new growth that is naturally infested in the nursery will have lower densities of mycelium present.

Submerging stem cuttings of 'Gumpo White' azalea in $50{ }^{\circ} \mathrm{C}$ water for $21 \mathrm{~min}$ caused only minor leaf damage with a LfD less than 0.1 that is not expected to affect rooting ability. The LfD value, which ranges from 0 to 0.75 , was used to quantify leaf damage resulting from hot water treatments. Research (Reuveni and Raviv, 1981; van Overbeek et al., 1946) shows that a reduction in leaf area can negatively impact rooting, and this general knowledge has been noted previously (Baker, 1962; Riehl, 1956). Because published information relating leaf area damage to rooting efficacy was not found, the $0.25 \mathrm{LfD}$ value (also the midpoint value of the lower leaf damage category) was selected as a conservative threshold based on distribution of LfD values in Figures 1 and 2. The effect of leaf damage on root development still needs to be critically evaluated. Further study is also needed to establish 

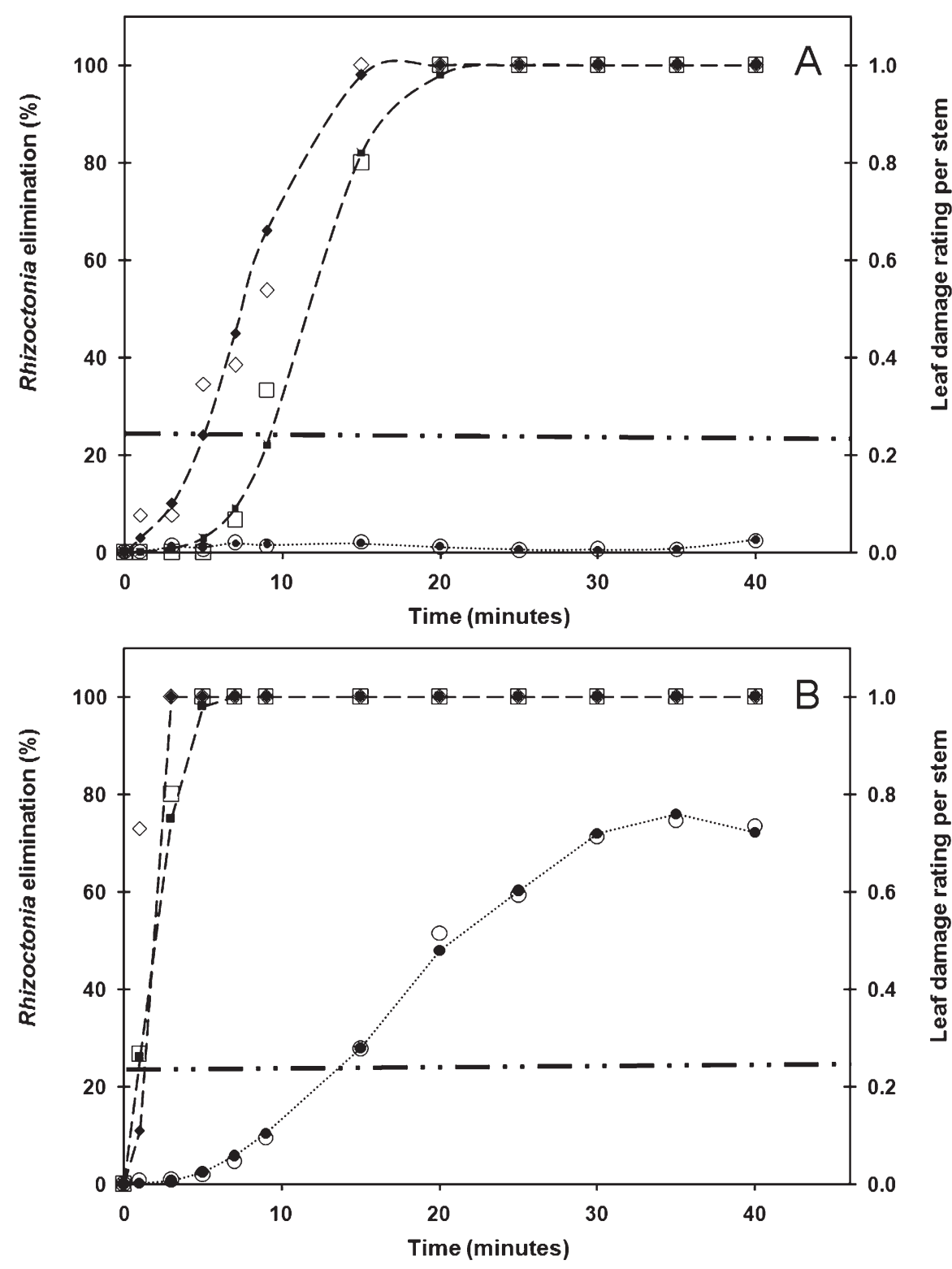

Fig. 1. Elimination of Rhizoctonia AG P from stem pieces (long-dashed lines; diamonds = Run 1 and squares $=$ Run 2) and leaf damage (rating of 0 to 0.75 ) on terminal stem cuttings (dotted lines; circles = runs combined) of 'Gumpo White' azalea in response to submersion for 0 to 40 min in hot water at (A) $50{ }^{\circ} \mathrm{C}$ and $(\mathbf{B}) 55^{\circ} \mathrm{C}$. Open symbols are means and filled symbols are predicted values. Leaf damage above 0.25 , represented by the horizontal dashed and dotted line, is considered the point at which damage to the stem cutting may decrease stem survivability.

sensitivity of azalea cultivars, other than 'Gumpo White', to thermotherapy.

Accuracy of water temperature and duration of submersion is critical for achieving pathogen mortality without damaging plant tissue (Grondeau and Samson, 1994; Lurie, 2006). Water temperature and duration of exposure found to eliminate Rhizoctonia from azalea stem pieces generally fall within the range of temperatures and durations that have been successful with other pathogens and plant material (Yarwood, 1975). Various plant species are tolerant of a water temperature that reduces pathogen viability such as onions in $45^{\circ} \mathrm{C}$ water for 8 to $12 \mathrm{~h}$ to reduce infection by Botrytis allii (Grondeau and Samson, 1994), bare-rooted palms in $50{ }^{\circ} \mathrm{C}$ water for 15 min to control burrowing nem- min followed by $50{ }^{\circ} \mathrm{C}$ water for $3 \mathrm{~min}$, but vigor and survival of some cultivars were reduced at those temperatures and durations. Vegetative growth of strawberry nursery stock was minimally damaged when bagged nursery plants were exposed to dry or wet heat of $44{ }^{\circ} \mathrm{C}$ for $4 \mathrm{~h}$ or $48{ }^{\circ} \mathrm{C}$ for $2 \mathrm{~h}$ (Turechek and Peres, 2009). These temperatures and durations did not eliminate the pathogen, but caused a reduction of $10^{5}$ or $10^{6}$ colony-forming units $/ \mathrm{mL}$ of Xanthomonas fragariae, the cause of angular leaf spot.

It is unfortunate that Rhizoctonia AG P was not inhibited by treatment of stem pieces with disinfestants (sodium hypochlorite, hydrogen dioxide, and quaternary ammonium chloride) and fungicides (chlorothalonil + thiophanate methyl, and flutolanil), because these would have provided additional treatment options. Reasons why posttreatments were ineffective was not determined. One possible explanation is the pathogen avoided contact with the chemicals by the mycelium growing within the irregular bark crevices of the azalea stem or penetrating into intracellular or intercellular plant spaces. If this occurred, the untreated mycelium could retain viability even if some mycelium died from chemical contact. A surfactant was mixed with sodium hypochlorite for one treatment in Expt. 4, but this did not reduce recovery of Rhizoctonia AG P. Other research approaches such as application of a disinfestant as a gas and histopathologic evaluation of plant tissue were not attempted and would have provided additional experimental evidence.

Although disinfestants can effectively kill pathogens (Copes, 2004), other studies have reported variable levels of control responses. Chlorine and hydrogen peroxide reduced Salmonella on muskmelon surfaces, yet a greater reduction resulted from submersion in $96{ }^{\circ} \mathrm{C}$ water for 2 min (Ukuku, 2006). Chlorine treatments reduced the incidence of three fungal pathogens on spinach seed but were not as effective as submersion in 40 to $60{ }^{\circ} \mathrm{C}$ water for 10 to $30 \mathrm{~min}$ depending on the pathogen (du Toit and Hernandez-Perez, 2005). Submersion of onion seed in $50{ }^{\circ} \mathrm{C}$ water for $20 \mathrm{~min}$ reduced incidence of two pathogens more consistently than sodium hypochlorite or fungicides (Aveling et al., 1993). Postharvest treatment of seed potatoes with a combination of disinfestants and fungicides reduced rot severity by $R$. solani (Burth et al., 1978; Errampalli et al., 2006). Errampalli et al. (2006) deduced that chlorine dioxide may have killed the majority of sclerotia, whereas thiophanate-methyl in combination suppressed growth of $R$. solani. Some studies have reported improved disease control by combining chemical and hot water treatments (Porat et al., 2002; Sharma and Tripathi, 2008). Hot water $\left(41^{\circ} \mathrm{C}\right)$ submersion of acorns for $2.5 \mathrm{~h}$ prolonged seed storage by controlling Sclerotinia pseudotuberosa (Finch-Savage et al., 2003). The addition of fungicides (benomyl and/or thiram) to the hot water further improved the storage life of acorns. 

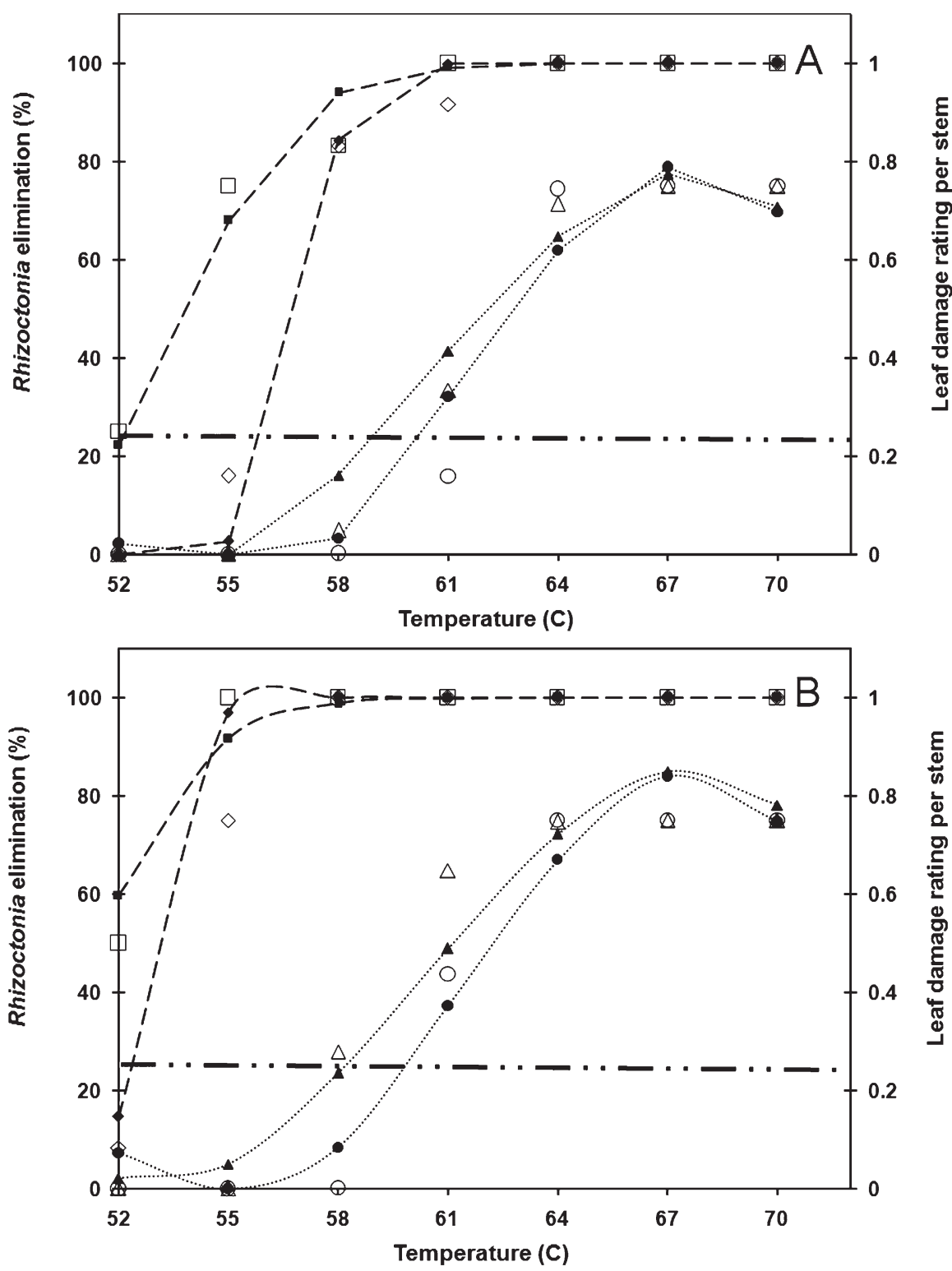

Fig. 2. Elimination of Rhizoctonia AG P from stem pieces (long-dashed lines; diamonds $=$ Run 1 and squares $=$ Run 2 ) and leaf damage (rating of 0 to 0.75 ) on terminal stem cuttings (dotted lines; triangles $=$ Run 1 and circles $=$ Run 2) of 'Gumpo White' azalea in response to submersion in hot water at 52 to $70{ }^{\circ} \mathrm{C}$ for (A) $30 \mathrm{~s}$ and (B) $60 \mathrm{~s}$. Open symbols are means and filled symbols are predicted values. Leaf damage above 0.25 , represented by the horizontal dashed and dotted line, is considered the point at which damage to the stem cutting may decrease stem survivability.

Table 3. Frequency of damage to terminal stem cuttings of 'Gumpo White' azalea resulting from submersion in $55^{\circ} \mathrm{C}$ water for various durations.

\begin{tabular}{llccc}
\hline & & \multicolumn{3}{c}{ Frequency of cuttings with leaf damage $^{\mathrm{y}}$} \\
\cline { 3 - 5 } Duration $(\mathrm{min})$ & $\mathrm{n}^{\mathrm{z}}$ & None & Moderate & Severe \\
\hline 0 & 12 & 12 & 0 & 0 \\
5 & 12 & 7 & 5 & 0 \\
25 & 12 & 0 & 4 & 8 \\
45 & 12 & 0 & 0 & 12 \\
\hline
\end{tabular}

${ }^{\mathrm{z}}$ Frequencies are combined data from two runs (repeated experiment).

${ }^{\mathrm{y}}$ Damage to stem cuttings was categorized as none (all leaves green and healthy in appearance), moderate (LfD 0.25 or less; should not affect success of rooting), and severe (LfD greater than 0.25 ; likely to affect rooting success). LfD is a "leaf damage" value whereby the likelihood of a stem cutting to not successfully develop roots would be correlated to the proportional number of leaves per stem that were healthy, had less than $50 \%$ necrotic area, and had greater than $50 \%$ necrotic area.

We have determined from other research that the Rhizoctonia population persists from year to year within a container-grown azalea plant (W.E. Copes, unpublished data). Use of greenhouses are conducive to spread of Rhizoctonia spp. from cutting to cutting, possibly similar to the colonization of foam rooting cubes (Benson, 1991, 1992). It is likely that additional mechanisms of spread, from routine plant handling activities and wind-disseminated plant debris, may contribute to the wide dispersal of Rhizoctonia on azaleas in nurseries. The long-term goal of achieving Rhizoctonia-free plants involves first obtaining pathogen-free propagation material.

Although posttreatment of azalea stem pieces with disinfestants and fungicides was not effective, additional research is planned to investigate field application of fungicides and posttreatments with alternative application methods and chemical mixtures. We used hot water submersion as the form of thermotherapy; however, further study could be valuable in developing more comprehensive guidelines, including use of alternative heat application methods such as hot air and vapor-heat treatments.

\section{Literature Cited}

Amadioha, A.C. 1998. Control of post harvest tuber rot of potato incited by Rhizoctonia bataticola. Arch. Phytopathol. Plant Prot. 31: 225-231.

Aveling, T.A.S., H.G. Snyman, and S.P. Naude. 1993. Evaluation of seed treatments for reducing Alternaria porri and Stemphylium vesicarium on onion seed. Plant Dis. 77:1009-1011.

Baker, K.F. 1962. Thermotherapy of plant material. Phytopathology 52:1244-1255.

Baker, K.F. and C.N. Roistacher. 1972. Heat treatment of soil, p. 123-137. In: Baker, K.F. (ed.). The U.C. system for producing healthy container-grown plants. Calif. Agr. Exp. Sta. Manual 23. University of California Division of Agricultural Sciences, Berkeley, CA.

Benson, D.M. 1991. Control of Rhizoctonia stem rot of poinsettia during propagation with fungicides that prevent colonization of rooting cubes by Rhizoctonia solani. Plant Dis. 75: 394-398.

Benson, D.M. 1992. Detection by enzyme-linked immunosorbent assay of Rhizoctonia species on poinsettia stem cuttings. Plant Dis. 76:578581 .

Burth, U., J. Pfaumbaum, and G. Brazda. 1978. Preservation of healthy planting material for disinfection. Nachrich. Pflanz. DDR 32:105110.

Chase, A.R. 1991. Characterization of Rhizoctonia species isolated from ornamentals in Florida. Plant Dis. 75:234-238.

Clarke, K., V. Sergeeva, R.W. Emmett, and N.G. Nair. 2004. Survival of Phomopsis viticola in grapevine cuttings after hot water treatment. Australas. Plant Pathol. 33:317-319.

Copes, W.E. 2004. Dose curves of disinfestants applied to plant production surfaces to control Botrytis cinerea. Plant Dis. 88:509-515.

Dashwood, E.P., E.M. Burnett, and M.C.M. Perombelon. 1991. Effect of a continuous hot water treatment of potato tubers on seed-borne fungal pathogens. Potato Res. 34:71-78.

Daughtrey, M.L. and D.M. Benson. 2005. Principles of plant health management for ornamental plants. Annu. Rev. Phytopathol. 43: 141-169.

du Toit, L.J. and P. Hernandez-Perez. 2005. Efficacy of hot water and chlorine for eradication 
of Cladosporium variabile, Stemphylium botryosum, and Verticillium dahliae from spinach seed. Plant Dis. 89:1305-1312.

Errampalli, D., R.D. Peters, K. MacIssac, D. Darrach, and P. Boswall. 2006. Effect of a combination of chlorine dioxide and thiophanate-methyl pre-planting seed tuber treatment on the control of black scurf of potatoes. Crop Prot. 25:1231-1237.

European and Mediterranean Plant Protection Organization. 1994. Guidelines on good plant protection practice: Potato. Bull. OEPP 24: 825-845.

Finch-Savage, W.E., H.A. Clay, S.P. Budge, K.C. Dent, J.P. Clarkson, and J.M. Whipps. 2003. Biological control of Sclerotinia pseudotuberosa and other fungi during moist storage of Quercus robur seeds. Eur. J. Plant Pathol. 109: 615-624.

Fleury, P. 1992. Flutolanil: A fungicide for treatment of potato plants. Phytoma 82:65-66.

Frisina, T.A. and D.M. Benson. 1989. Occurrence of binucleate Rhizoctonia spp. on azalea and spatial analysis of web blight in containergrown nursery stock. Plant Dis. 73:249-254.

Grondeau, C. and R. Samson. 1994. A review of thermotherapy to free plant materials from pathogens, especially seeds from bacteria. Crit. Rev. Plant Sci. 13:57-75.

Johnson, A.W., D.W. Simpson, and A. Berrie. 2006. Hot water treatment to eliminate Colletotrichum acutatum from strawberry runner cuttings. Acta Hort. 708:255-257.

Keck, M., R. Chartier, W. Zislavsky, P. Lecomte, and J.P. Paulin. 1995. Heat treatment of plant propagation material for the control of fire blight. Plant Pathol. 44:124-129.

Lewis, J.A., R.D. Lumsden, G.C. Papavizas, and J.G. Kantzes. 1983. Integrated control of snap bean diseases caused by Pythium spp. and Rhizoctonia solani. Plant Dis. 67:1241-1244.
Lurie, S. 2006. The effect of high temperature treatment on quality of fruits and vegetables. Acta Hort. 712:785-792.

Mannini, F. 2007. Hot water treatment and field coverage of mother plant vineyards to prevent propagation material from phytoplasma infections. Bull. Insectology 60:311-312.

Mari, M., F. Neri, and P. Bertolini. 2007. Novel approaches to prevent and control postharvest diseases of fruits. Stewart Postharvest Rev. 3: 11-13.

Porat, R., A. Daus, B. Weiss, L. Cohen, and S. Droby. 2002. Effects of combining hot water, sodium bicarbonate and biocontrol in postharvest decay of citrus fruit. J. Hortic. Sci. Biotechnol. 77:441-445.

Reuveni, O. and M. Raviv. 1981. Importance of leaf retention to rooting of avocado cuttings. J. Amer. Soc. Hort. Sci. 106:127-130.

Ricker, M.D. and Z.K. Punja. 1991. Influence of fungicide and chemical salt dip treatments on crater rot caused by Rhizoctonia carotae in long-term storage. Plant Dis. 75:470-474.

Riehl, G. 1956. The effect of various environmental conditions on the propagation of ornamental plants by cuttings with the aid of sub-irrigaiton. Arch. Gartenb. 4:433-522.

Rinehart, T.A., W.E. Copes, T. Toda, and M.A Cubeta. 2007. Genetic characterization of binucleate Rhizoctonia species causing web blight on azalea in Mississippi and Alabama. Plant Dis. 91:616-623.

Salami, A.O. and O.O. Popoola. 2007. Thermal control of some post-harvest rot pathogens of Irish potato (Solanum tuberosum L.). J. Agr. Sci. 52:17-31.

Sharma, N. and A. Tripathi. 2008. Integrated management of postharvest Fusarium rot of gladiolus corms using hot water, UV-C and Hyptis suaveolens (L.) Poit. essential oil. Postharvest Biol. Technol. 47:246-254.
Smith, M.A.L. and D. Neely. 1981. Screening woody ornamental cuttings for propagation diseases. Plant Dis. 65:893-895.

Tsang, M.M.C., A.H. Hara, and B. Sipes. 2003. Hot-water treatments of potted palms to control the burrowing nematode, Radopholus similis. Crop Prot. 22:589-593.

Tsror, L. and I. Peretz-Alon. 2005. The influence of the inoculum source of Rhizoctonia solani on development of black scurf on potato. J. Phytopathol. 153:240-244.

Turechek, W.W. and N.A. Peres. 2009. Heat treatment effects on strawberry plant survival and angular leaf spot, caused by Xanthomonas fragariae, in nursery production. Plant Dis. 93: 299-308.

Ukuku, D.O. 2006. Effect of sanitizing treatments on removal of bacteria from cantaloupe surface, and re-contamination with Salmonella. Food Microbiol. 23:289-293.

van Overbeek, J., S.A. Gordon, and L.E. Gregory. 1946. An analysis of the function of the leaf in the process of root formation in cuttings. Amer. J. Bot. 33:100-107.

Weinhold, A.R., T. Bowman, and D.H. Hall. 1982. Rhizoctonia disease of potato: Effect on yield and control by seed tuber treatment. Plant Dis. 66:815-818.

Williams-Woodward, J. and R.K. Jones. 2001. Sanitation: Plant health from start to finish, p. 384-368. In: Jones, R.K. and D.M. Benson (eds.). Diseases of woody ornamentals and trees in nurseries. APS Press, St. Paul, MN.

Yarwood, C.E. 1975. Temperature coefficients in plant pathology. Phytopathology 65:1198-1201.

Yuan, G.Q., A. Kamio, B.S. Sharma, Y. Sagara, M. Arakawa, and K. Inagaki. 2006. Survival and subsequent dispersal of rice sclerotial disease fungi, Rhizoctonia oryzae and Rhizoctonia oryzae-sativae, in paddy fields. Plant Dis. 90: 615-622. 